\title{
Guideline for oral care of dependent elders: mapping review and cross-cultural adaptation to Portuguese-Brazil
}

Rafaella Mendes de JESUS ${ }^{(a)}$

Fernanda Lamounier CAMPOS(a) Lorrany Gabriela RODRIGUES(a)

Matheus de França PERAZZO(a) iD

Anna Rachel dos Santos

SOARES(a)

Marco Túlio de Freitas RIBEIRO(b) iD

Aline Araújo SAMPAIO(c) ID

Raquel Conceição FERREIRA(d)

(a) Universidade Federal de Minas Gerais UFMG, School of Dentistry, Belo Horizonte, $M G$, Brazil.

(b)Fundação Hospitalar do Estado de Minas Gerais - FHEMIG, Betim, MG, Brazil.

(c) Universidade Federal de Minas Gerais UFMG, School of Dentistry, Department of Clinical, Pathology and Dental Surgery, Belo Horizonte, MG, Brazil.

(d) Universidade Federal de Minas Gerais UFMG, School of Dentistry, Department of Community and Preventive Dentistry, Belo Horizonte, MG, Brazil.

Declaration of Interests: The authors certify that they have no commercial or associative interest that represents a conflict of interest in connection with the manuscript.

Corresponding Author:

Raquel Conceição Ferreira

E-mail: raquelcf@ufmg.br

ht1ps://doi.org/10.1590/1807-3107bor-2020.vol34.0097

Submitted: January 20, 2020

Accepted for publication: April 8, 2020

Last revision: July 17, 2020
Abstract: This study aimed to map evidence-based guidelines for oral care of the dependent elders and perform the cross-cultural adaptation to Brazilian Portuguese. Initially, a systematized review was conducted in Medline, Scielo, Scopus, Web of Science, and Google Scholar databases without restrictions in search period or type of study. Articles in English, Spanish, and Brazilian Portuguese describing evidence-based guidelines for oral care, including oral hygiene recommendations, of institutionalized dependent elders were included as long as they presented an evaluation of evident quality. The guideline that met inclusion criteria was submitted to cross-cultural adaptation after obtaining permission from the original authors. Two hundred and nineteen references were found. Three selected articles described evidence-based guidelines for oral care, but the Oral Health Care Guideline for Older People in Long-term Care Institutions (OGOLI), originally developed and implemented in the Netherlands, was selected. It was based on evidence level A2 and consensus of experts and met the quality requirements of the Appraisal of Guidelines for Research \& Evaluation (AGREE). This guideline presents oral care recommendations for elders with different levels of dependence in activities of daily living to be performed by caregivers and nursing staff. The adaptation of the OGOLI was mainly on the attributions of care providers, given the differences in professional regulations between Brazil and the Netherlands. The cross-cultural equivalence between OGOLI and its Brazilian Portuguese version was verified.

Keywords: Practice Guideline; Oral Health; Oral Hygiene; Frail Elderly; Long-Term Care.

\section{Introduction}

Population aging is a worldwide phenomenon. In Brazil, about $11 \%$ of the population was $\geq 60$ years $^{1}$ in 2010. In 2025, Brazil is projected to have the sixth largest population of older adults worldwide. ${ }^{2}$ Population aging is accompanied by an increased occurrence of morbidity, functional decline, and risk of dependence for basic Activities of Daily Living (ADL). ${ }^{3}$ 
Individuals who depend on help for ADL may also need help for oral hygiene activities, ${ }^{4}$ due to their inability to remove oral biofilm. ${ }^{5}$ Biofilm accumulation is associated with systemic disease risk such as malnutrition, ${ }^{6}$ respiratory tract infections, and pneumonia, especially in frail elders. ${ }^{7}$ Furthermore, another possible consequence of biofilm accumulation is the occurrence of oral diseases such as dental caries, periodontal disease, and mucosal lesions, such as denture stomatitis. ${ }^{8}$

Routine systematic oral hygiene must be part of oral care programs for dependent elders, ${ }^{9}$ with positive effects on health and quality of life. ${ }^{10}$ In the context of Long-Term Care Institutions for the Elderly (LTCI), caregivers and nursing staff assume an essential role in the oral hygiene of elders. Systematic reviews have evaluated different oral health educational interventions to train nursing staff and residents on oral hygiene. ${ }^{11,12}$ Because of the heterogeneity and the small number of studies in the literature, it is not possible to consistently determine the effectiveness of these programs and identify recommendations to be applied in oral health care. ${ }^{12}$

In Brazil, previous studies showed a lack of standardization of oral hygiene performed in LTCI and evidence-based guidelines for such care ${ }^{13}$. A systematic review did not find any guidelines for oral managing and caring for elders in LTCI developed in the country. ${ }^{14}$

Guidelines might ensure that patients receive appropriate care. They summarize the current knowledge, give specific recommendations based on this information, and should provide scientific evidence supporting those recommendations. Guidelines must be updated regularly. ${ }^{15}$ Therefore, oral health guidelines can improve quality and support evidence-based health care ${ }^{16}$ in the LTCI context. Guidelines should ideally include oral hygiene recommendations, a regular collaboration of dental professionals, and an ongoing training program for nursing staff and caregivers on oral health issues. ${ }^{17}$

This study aimed to map evidence-based guidelines for the oral care of dependent elders, including oral hygiene recommendations, and perform a cross-cultural adaptation of such guidelines to Brazilian Portuguese.

\section{Methodology}

\section{Literature search}

The mapping review aimed to identify the available guidelines for oral care of institutionalized dependent elders. A PRISMA flow diagram guided the selection of studies. ${ }^{18}$ The research question was: "Which guidelines for oral health care of dependent elderly people, including oral hygiene procedures, are being used?" The inclusion criteria were mainly based on guideline features: a) guidelines for oral care including oral hygiene recommendations; b) guidelines for institutionalized dependent elders; c) evidence-based guidelines; d) guidelines including a description of quality evaluation of chosen scientific evidence. Additionally, articles wrote in English, Spanish, and Brazilian Portuguese, without restrictions on search period or type of study, were included. Theses, dissertations, abstracts, editorials, unpublished articles, conference reports were not considered. Studies that did not satisfy the above-listed criteria were excluded: a) Guidelines did not aim dependent elders; b) Guidelines not specific for oral health; c) Guidelines without oral care or oral hygiene recommendations; d) Guidelines were not evidence-based.

An electronic literature search carried out from February to March 2020 in the Medline, Scopus, Web of Science, and Scielo databases identified the relevant studies. The search approach used for each database is shown in Table 1. The search approach in the Scielo database was less restrictive because the complete approach found no study. Besides, a manual search of Google Scholar was conducted, and the results from the first ten pages were ordered by relevance for identifying other pertinent studies.

All the database search outcomes were transferred to the Endnote $X 8^{\circledR}$ - reference management software, which was used to create a library for this review. After removing the duplicated articles, two trained independent reviewers completed the screening of studies by reading the title and abstract. The full-text studies were screened for eligibility. Discrepancies resulting from article screening were discussed further to reach consensus. In cases of persistent doubt, a third experient reviewer was consulted. 
Table 1. Approaches adopted to electronic search in Medline, Scopus, Web of Science, Scielo and Google Scholar databases.

\begin{tabular}{|c|c|}
\hline Medline & 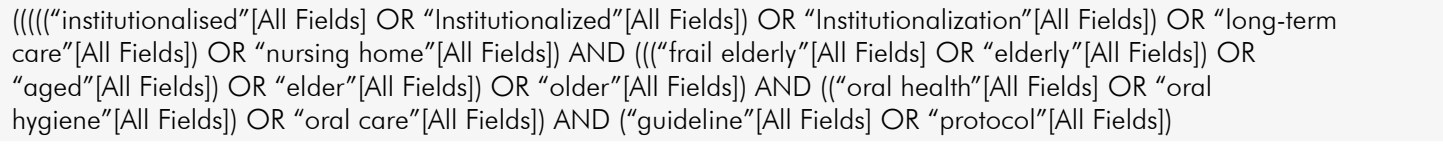 \\
\hline Scopus & $\begin{array}{l}\text { ( TITLE-ABS-KEY ( "protocol") ) OR TITLE-ABS-KEY ( "guideline" ) AND TITLE-ABS-KEY ( "institutionalised" ) OR } \\
\text { TITLE-ABS-KEY ( "institutionalized" ) OR TITLE-ABS-KEY ( "Institutionalization" ) OR TITLE-ABS-KEY ( "long-term care" ) } \\
\text { OR TITLE-ABS-KEY ( "nursing home" ) AND TITLE-ABS-KEY ( "elderly" ) OR TITLE-ABS-KEY ( "elder" ) OR TITLE-ABS-KEY } \\
\text { ( "older") OR TITLE-ABS-KEY ( "aged") OR TITLE-ABS-KEY ( "frail elderly" ) AND TITLE-ABS-KEY ( "oral care" ) OR } \\
\text { TITLE-ABS-KEY ( "oral hygiene" ) OR TITLE-ABS-KEY ( "oral health" ) ) }\end{array}$ \\
\hline Web of Science & $\begin{array}{l}\text { (TS = (("guideline" OR "protocol") AND ("oral health" OR “ORAL CARE" OR "oral hygiene") AND ("frail elderly" OR "aged" } \\
\text { OR "ELDER" OR "OLDER") AND ("institutionalised" OR "institutionalization" OR “long term care" OR "nursing home"))) }\end{array}$ \\
\hline Scielo & (ab:((("guideline”) OR (“protocol”)) AND ((“Oral hygiene") OR (“oral health”) OR (“Oral care”)))) \\
\hline Google Scholar & $\begin{array}{l}\text { ("institutionalised" OR "Institutionalized" OR "Institutionalization" OR "long-term care" OR "nursing home") AND ("frail } \\
\text { elderly" OR "elderly" OR "aged" OR "elder" OR "older") AND ("oral health" OR "oral hygiene" OR "oral care") AND } \\
\text { ("guideline" OR "protocol") }\end{array}$ \\
\hline
\end{tabular}

A secondary search of the reference list of all included studies was performed. The selected studies were analyzed and described. Studies that met all previously defined inclusion criteria were submitted to cross-cultural adaptation.

\section{Cross-cultural adaptation}

The Oral Health Care Guideline for Older People in Long-term Care Institutions (OGOLI) ${ }^{19}$ was the selected guideline for cross-cultural adaptation because it was evidence-based and met the requirements of the Appraisal of Guidelines for Research \& Evaluation (AGREE). The AGREE consists of 23 items to assess the quality of guidelines, including the methodological rigor and transparency in which a guideline is developed. It has six quality domains: scope and purpose, stakeholder involvement, rigorous development, clarity and presentation, applicability, and, lastly, editorial independence..$^{20}$

After obtaining permission for the OGOLI use in Brazil from the original authors, this guideline was submitted to the cross-cultural adaptation according to internationally accepted guidelines (Figure 1). ${ }^{21,22}$

The guideline was independently translated from English to Brazilian Portuguese by two native Portuguese speakers who are also proficient in English (T1 and T2). One of the translators had a background in dentistry, and the other did not know the research subject.

The synthesis version (T1.2) was obtained by comparison of the $\mathrm{T} 1$ and $\mathrm{T} 2$. The experts discussed the translated guideline item-by-item of (T1, T2) until consensus. In this step, the objective was to obtain the semantic and conceptual equivalence.

The T1.2 version of the guideline in Portuguese was back-translated (R1) into English. The translator was a native English speaker fluent in Brazilian Portuguese and had no access to the original guideline. The backtranslation of the OGOLI was sent to the original authors by e-mail for their evaluation. After receiving the results of this evaluation, the experts met again to review all versions (T1, T2, T1.2, R1) and compare the original version of the OGOLI with its back-translation, taking into consideration the authors' comments. Each expert reviewed the material independently. Based on the results of the preceding phase, the experts proposed a final version of the OGOLI, which was written in Brazilian Portuguese and intended to be used in an implementation study in LTCI.

\section{Results}

We found 283 articles: 95 in Medline, 99 in Scopus, 26 in Web of Science, and 63 in Scielo (Figure 2). Google Scholar search did not return new relevant references besides those already identified in other databases. After excluding duplicate references, 219 articles remained. After screening, 7 articles that did not address any aspect of oral health were excluded. Other 195 articles were excluded because they did not describe oral care guidelines, or guidelines were not about oral health care for dependent elders. Seventeen full-text articles were assessed for eligibility because they described oral care guidelines for dependent 


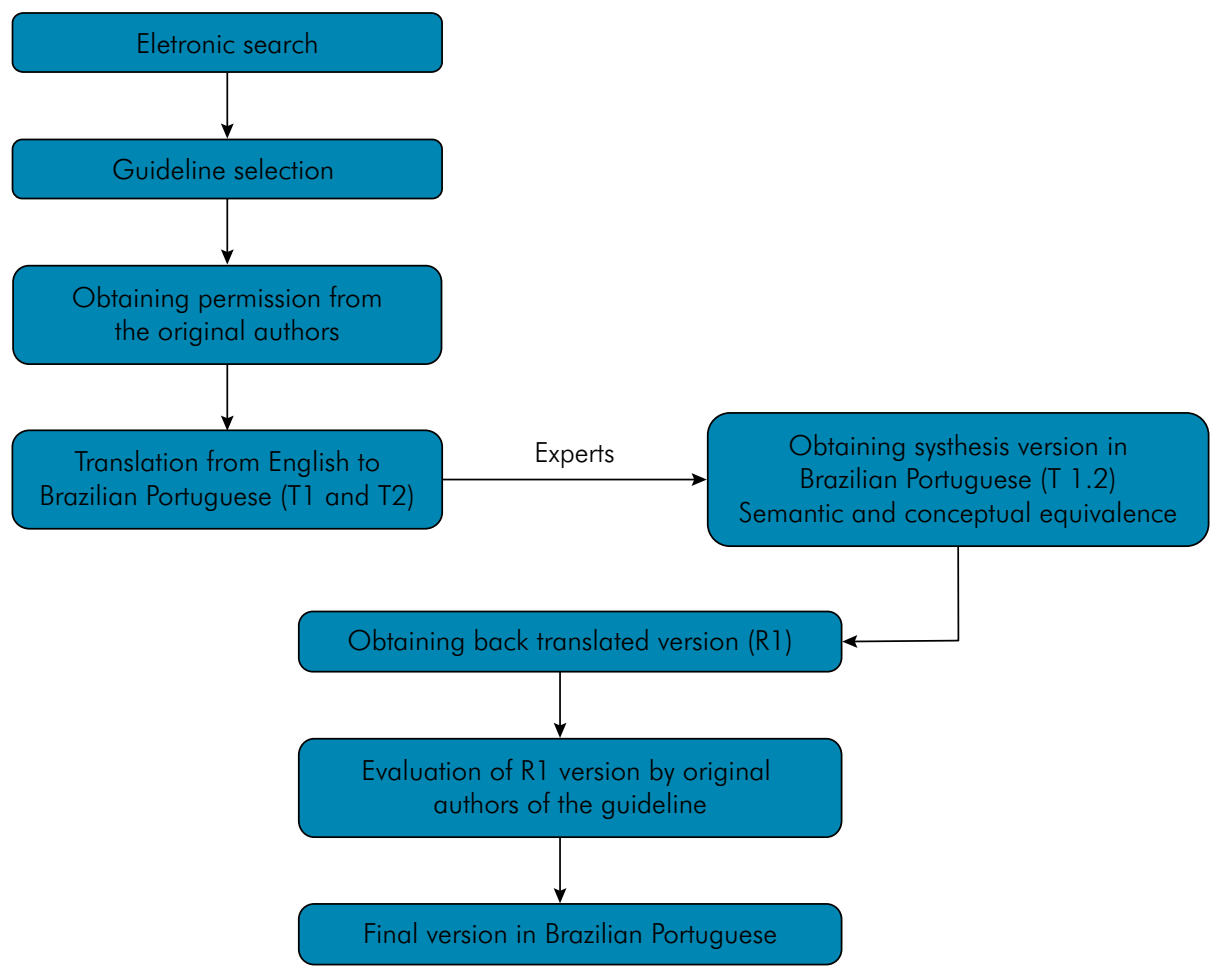

Figure 1. Steps followed for translation and cross-cultural adaptation of the Oral Health Care Guideline for Older People in Long-term Care Institutions (OGOLI) from English to Brazilian Portuguese

elders, of which 14 were excluded: eight were studies on evaluation of the OGOLI implementation and six were about other guidelines for oral care without a description of specific recommendations. In the end, three articles were selected, which addressed and described oral care guidelines for dependent older people, including oral hygiene recommendations. ${ }^{17,19,23}$

Gil-Montoya et al. ${ }^{17}$ developed an oral health care guideline for elderly patients admitted to the San Rafael Hospital in Granada, Spain. The authors recommended an initial assessment of the consciousness of the elders. The guideline required a brief oral health history evaluation as the basis for individualized planning by the physician or dental surgeon. Sarin et al. ${ }^{23}$ provided specific guidelines on oral health care to reduce the risk of respiratory pneumonia in elders residing in longterm care institutions.

Although these two studies described oral care guidelines, they have not undergone a quality assessment, and most of the recommendations were based on the consensus of experts. Also, these two articles are older than the ones selected for cross-cultural adaptation.

De Visschere et al. ${ }^{19}$ described an oral health care guideline for dependent patients (OGOLI), aiming to improve the oral health of institutionalized elders. Besides describing specific oral care orientations, with oral hygiene recommendations, to be developed by the nursing staff, the guideline defined three key points for its implementation: integrated nursing care, permanent education of the nursing staff, and continuous monitoring of implementation. Thereby, the aim was to incorporate oral health care into daily nursing care. ${ }^{19,24}$

The evidence-based recommendations of OGOLI were related to health education, prevention of aspiration pneumonia, and the use of electric toothbrush and fluoride rinses when the elder presents a sudden increase in visible biofilm. The evidence on which the guideline was based was level A2 (good-quality, double-blind, randomized, controlled trial). Part of the recommendations was based on expert consensus. The authors stated 

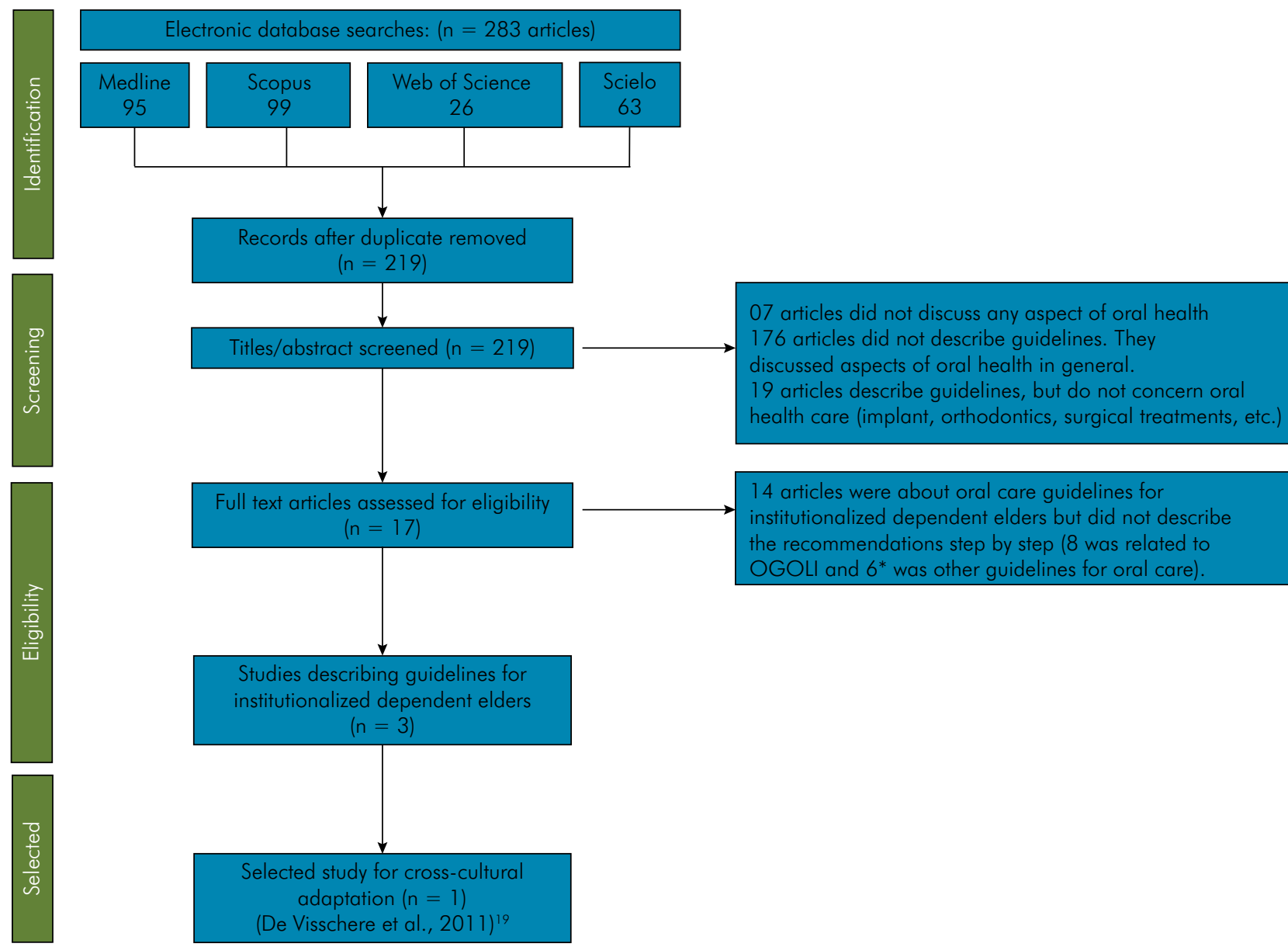

14 articles were about oral care guidelines for

institutionalized dependent elders but did not describe the recommendations step by step (8 was related to OGOLI and $6 *$ was other guidelines for oral care)

*1. Chalmers J, Johnson V, Tang JH, Titler MG. Evidence-based protocol: oral hygiene care for functionally dependent and cognitively impaired older adults. J Gerontol Nurs. 2004 Nov;30(1 1):5-12. https://doi.org/10.3928/0098-9134-20041101-06

2. Dyck D, Bertone M, Knutson K, Campbell A. Improving oral care practice in long-term care. Can Nurse. 2012 Nov; 108(9):20-4.

3. Kelson AE, Thomson WM, Love RM. Oral health protocols in care facilities for older people in New Zealand. N Z Dent J. 2016;1 12(3):88-95.

4. Lloyd PM, Gambert SR. Guidelines for oral health care of the institutionalized elderly. Wis Med J. 1983 Sep;82(9):28-30.

5. Marchini L, Recker E, Hartshorn J, Cowen H, Lynch D, Drake D, et al. lowa nursing facility oral hygiene (INFOH) intervention: A clinical and microbiological pilot randomized trial. Spec Care Dentist. 2018 Nov;38(6):345-55. https://doi.org/10.1 111 /scd. 12327

6. Park Y, Oh S, Chang H, Bang HL. Effects of the evidence-based nursing care Algorithm of dysphagia for nursing home residents. J Gerontol Nurs. 2015 Nov; 41 (1 1):30-9. https://doi.org/10.3928/00989134-20151015-04

Figure 2. Flowchart of the literature review process for studies on guidelines for oral care of dependent elders.

the importance of a prescription from a qualified professional when chlorhexidine and fluorine were needed. Regarding the mechanical procedure for oral hygiene, the guideline states that an electric toothbrush

Table 2. Cross-cultural adaptations of the Oral Health Care Guideline for Older People
1) Replacement of "geriatrician" by "nursing team professional" or "dentist", according to professional attributions in Brazil.
2) Replacement of Ward Oral Health Care Organizer (WOO) by Responsible Technician Nurse according to professional attributions in Brazil.
3) Replacement of Dental Hygienist by Oral Health Technician according to professional attributions in Brazil.
4) Replacement of "geriatrician" by "doctor responsible for the care of the elders" considering the organizational services in Brazil.
5) Replacement of "dentist of the institution" by "dental reference service" considering the organizational services in Brazil.
6) The word "institution" was used in conjunction with "ward" to describe organization division of institutions (institution/ward).
7) Replacement of continuing education by "educação permanente" (permanent education), the best expression for continuing education in Brazil. 
can contribute significantly to oral health care. Given that this guideline was based on scientific evidence and focused on the oral health care of dependent elders in LTCI, it was selected for translation and cross-cultural adaptation. The adaptation of the OGOLI to the Brazilian context was mainly concerning the professional regulation of health providers and the organization of health services in Brazil (Table 2).

The original authors of OGOLI recommended removing "Oral Health Technician (OHT)" from the description of key point 2 when they analyzed the back-translated version. They asked "to delete the word OHT since that country does not have this professional in the context of the OGOLI." Thus "OHT" was used to replace to "dental hygienist" from the original OGOLI, as the group of experts clarified to the author that the attributions of dental hygienists in the Netherlands correspond to those of the OHT in Brazil. With this, the authors validated the back-translated version. The authors were also consulted for clarification on the difference between recommendations 15 and 16. According to them, the 15th recommendation concerns dentate people for which regular, daily oral health care is difficult. It refers to the inability to perform routine oral health care in both older people and young people with disabilities. The 16th item concerns people for which provision of daily oral health care is not possible. Examples include terminally ill patients and resistance behavior of persons with dementia. The final Portuguese version is shown in Table 3.

\section{Discussion}

The establishment of an oral health care guideline for frail and functionally dependent elders to be followed by health professionals is an effective strategy for achieving quality care. ${ }^{17}$ OGOLI was considered the most appropriate guideline for dependent elders living in long-term care facilities. Cross-cultural adaptation is also important to ensure the validity of the guidelines in the Brazilian context, considering the linguistic and cultural characteristics of the place. ${ }^{22}$ This process enables the use of the existing guideline based on the literature, which saves considerable time and effort. ${ }^{25}$
OGOLI combines an evidence-based approach with formal or informal consensus methods, which has been observed for most guidelines. ${ }^{16}$ Besides, its implementation has been evaluated in clinical trials $\mathrm{s}^{26,27}$ and longitudinal studies. ${ }^{28,29}$ The evidence-based guidelines emphasize the importance of linking recommendations to supporting scientific research and is verified through rigorous identification and systematic evaluation of all relevant research. ${ }^{30}$ Four recommendations of OGOLI (health education, prevention of pneumonia, use of an electric toothbrush, and use of fluoride rinsing during a sudden increase in oral plaque) were based on the findings of level A2 evidence. The other recommendations were based on expert's consensus.

The back-translation resulted in a version similar to the original guideline, thus highlighting the adequacy of the Brazilian Portuguese version. The necessary adaptations of the Brazilian version were mainly due to differences in the LTCI organization, the composition, and assignments of the elderly care providers between the two countries.

OGOLI recommends that a geriatrician describes the oral health condition and refers the elder to the institution's dentist at the time of admission. For the cross-cultural adaptation, the term "geriatrician" was replaced by "professional nursing staff" since Brazilian LTCI often does not have a specialized geriatric doctor in the service. The "dentist at the institution" was replaced by "referral" corresponding to the dental reference service. This change was required since Brazilian LTCIs rarely have a dentist in place.

TheOGOLI recommends that a nursing professional be educated for oral health care, the so-called Ward Oral health care Organizer (WOO). This professional would be responsible for monitoring the adherence and compliance of the staff with the guideline and he or she must develop workshops and act as an intermediary between the nursing team and the oral health team. ${ }^{19}$ In the Brazilian context, the "Responsible Technician Nurse (RT)" is the professional responsible for promoting quality and development of nursing care through the implementation of health protocols and procedures. ${ }^{31}$ Therefore, the RT replaced the WOO. Additionally, as Brazilian LTCIs may not be divided by wards, the word "institution" was used in conjunction with "ward." 
Table 3. Long-term Care Institutions (OGOLI). ${ }^{19}$

Orientações de cuidados bucais para idosos em Instituições de Longa Permanência

Ponto-chave 1: Cuidados integrados em saúde bucal

De acordo com a OGOLI, todas as instituições de cuidado de longa permanência para idosos deveriam possuir orientações institucionais de cuidados bucais. O cuidado em saúde bucal deve ser individualizado e integrado aos cuidados de enfermagem de cada residente. No processo institucional de cuidados em saúde, organizados ciclicamente, o resultado dos cuidados em saúde bucal deve ser avaliado continuamente e ajustado quando necessário. Na admissão de um novo residente, um profissional da equipe de enfermagem deve descrever sua condição de saúde bucal e encaminhá-lo ao dentista em um serviço odontológico de referência. O profissional da equipe de enfermagem deve estar atento aos problemas de saúde bucal, os quais podem estar relacionados a saúde geral e vice-versa. $O$ enfermeiro responsável técnico (RT) de cada ala/instituição, deverá ser capacitado em saúde bucal e cuidados em saúde bucal, e ele será referência em saúde bucal da ala/instituição. O enfermeiro RT deve (i) monitorar a adesão da equipe de enfermagem ao OGOLl; (ii) monitorar a adequação dos programas de cuidados em saúde bucal à condição de cada residente; (iii) deve atuar como orientador de cuidados em saúde bucal para a equipe de enfermagem da ala/instituição; (iv) deve promover oficinas ou cursos sobre cuidados em saúde bucal à equipe de enfermagem da ala/instituição; e (v) deve intermediar o contato entre equipe de enfermagem, dentista, técnico em saúde bucal e médico responsável pelos cuidados do idoso.

Ponto-chave 2: Educação permanente da equipe de enfermagem

Foi demonstrado que a capacitação teórica e prática em saúde bucal da equipe de enfermagem melhora a saúde bucal dos residentes. No entanto, um único momento de capacitação não é suficiente para estabelecer um resultado duradouro. Após algum tempo, o efeito da capacitação diminui e a saúde bucal dos residentes piora. O OGOLI recomenda que o enfermeiro responsável técnico e outros membros da equipe de enfermagem sejam capacitados pelo menos a cada 18 meses, mas, de preferência anualmente. A capacitação ser ministrada por um dentista ou um técnico em saúde bucal que esteja atuando em um serviço odontológico de referência.

Ponto-chave 3: Monitoramento contínuo da implementação do OGOLI

O monitoramento da adesão ao OGOLl e da adequação do programa de saúde bucal à condição de cada residente é um fator crucial a implementação. Os indicadores de estrutura, processo e resultado devem ser usados em um processo recorrente para monitorar a implementação do OGOLI dentro do processo institucional de cuidados em saúde. Os indicadores de estrutura demonstram se os cuidados em saúde bucal estão bem integrados a realidade institucional dos cuidados em saúde. Indicadores de processo demonstram se a implementação do OGOLI está em conformidade aos programas individuais de cuidados em saúde bucal de cada residente. Os indicadores de resultado fornecem informações sobre o impacto do OGOLI, como, por exemplo, a quantidade de placa dos residentes.

\section{Orientações para a equipe de enfermagem}

1. Ofertar cuidados em saúde bucal sistematicamente para melhorar a qualidade de vida dos residentes.

2. Tentar prevenir a colonização por Candida na mucosa bucal, especialmente em usuários de prótese removível, dentados ou edentados. Ou tratar a infecção por meio de cuidados em saúde bucal sistemáticos.

3. Fornecer cuidados em saúde bucal pelo menos uma vez ao dia para diminuir o risco de infecção sistêmica, como a pneumonia.

4. Utilizar uma escova elétrica pode contribuir significativamente para o cuidado em saúde bucal.

5. Limpar a prótese removível parcial ou total quando o residente for dormir e armazená-la em local seco durante a noite.

6. Providenciar uma avaliação odontológica profissional para residentes dentados, pelo menos, a cada 6 meses.

7. Providenciar uma avaliação odontológica profissional para residentes que não apresentam dentição natural, usuários ou não de prótese removível, pelo menos, uma vez ao ano

8. No caso de um residente demonstrar ou parecer manifestar sinais (não-verbais) de dor na boca, tente examinar sua boca e/ou próteses e consulte um dentista ou um técnico em saúde bucal ou médico responsável pela saúde do idoso quando indicado ou questionável. Manifestações não verbais de dor na boca podem ser comportamento alterado, redução de apetite e perda de peso.

9. No caso de um residente ter mau hálito frequente, consulte um dentista.

10. No caso de um residente queixar-se de boca seca, consulte um dentista.

11. Avalie os possíveis efeitos colaterais bucais de medicamentos prescritos.

12. No caso de um residente queixar-se ou apresentar lesões em tecidos moles na boca, relacionados ou não à prótese, consulte um dentista.

13. No caso de um residente apresentar um aumento súbito de cárie, consulte um dentista e discuta a possibilidade de prescrição de bochecho com flúor 0,025-0,01\% diariamente ou 0,1\% semanalmente, quando indicado.

14. No caso de qualquer lesão dentária suspeita, observada durante os cuidados com saúde bucal, consulte um dentista.

15. No caso de impossibilidade dos cuidados diários em saúde bucal em um residente dentado devido a problemas físicos e/ou comportamentais, aplique gel de Clorexidina 1\% uma vez ao dia ou Gel de Clorexidina 0,5\% duas vezes ao dia para prevenção da doença periodontal. A clorexidina deve ser prescrita por um dentista.

16. Quando não for possível fornecer cuidados em saúde bucal diariamente, use um enxaguante bucal de clorexidina $0,12 \%$, ou um spray para uso diário. Caso o enxague ou a aplicação de spray não for possível, aplique um gel de clorexidina 1\% usando, por exemplo, uma gaze encharcada. A clorexidina deve ser prescrita por um dentista. 
The OGOLI defines attributions to "dental hygienist". In the Brazilian version, this term was replaced by "OHT", as dental hygienist category does not exist in Brazil. The attributions of dental hygienist correspond to those of the OHT in Brazil. Similarly, the "geriatrician" has been replaced by "attending physician," as often the practitioner may be a general physician or a professional of another medical specialty.

"Continuing education" is a strategy for the implementation of OGOLI. ${ }^{19}$ This activity in Brazil is best understood as "permanent education." Permanent health education is based on continuous learning. It aims to qualify health workers to care for the needs of the population, and it is characterized by training during routine work, transforming everyday situations into learning experiences, reflexively analyzing the problems of health practice and valuing the work process in its intrinsic context. ${ }^{32}$

In the item about dealing with the prevention of Candida colonization, the phrase "especially in users of removable dentures, dentate or edentulous" was added. In this way, the guidelines highlight the orientation, especially for residents who use dental prostheses and have the highest prevalence of candidiasis due to biofilm accumulation. ${ }^{8}$ The guideline recommends consultation with the geriatrician when a resident reports dry mouth. However, this professional was replaced by the dentist since the diagnosis and treatment of oral conditions are legal attributions of dentists in Brazil. ${ }^{33}$

The recommendation on the use of chlorhexidine proposed by the guideline is still valid in the current literature. A systematic review showed consistent evidence of dental biofilm reduction with chlorhexidine mouthwash as an adjunct in mechanical oral hygiene procedures. However, there is no evidence of a specific chlorhexidine concentration. ${ }^{34}$ Yet, caution should be exercised with prolonged use, as there are adverse effects such as extrinsic staining of teeth, stone accumulation, taste alteration, and effects on the oral mucosa. ${ }^{34}$

The literature shows considerable variation in current guidelines for care of people with dental prostheses, which can often be left undefined for both users and oral care providers. The British Gerodontology Society reinforces the need for daily cleaning of dentures to remove debris using a toothbrush and soap and then rinsing with water. It also recommends the prosthesis should not be kept immersed in a solution, just like OGOLI. This recommendation aims at preventing elders from confusing tablets for denture cleaning with their regular medication, especially effervescent tablets. As a consequence, elders could ingest these solutions, especially those with dementia or a visual impairment, causing severe effects on the respiratory and digestive tracts. ${ }^{35}$

The authors defined three key points for guideline implementation: integrated nursing care, permanent education of the nursing staff, and continuous monitoring of implementation. A randomized clinical trial showed the OGOLI-supervised implementation increased the knowledge of providers of oral health care in long-term care facilities. ${ }^{36}$ Scientific evidence also show that nursing staff training contributes to better oral hygiene of elders, as measured by dental biofilm and prosthetic indices. ${ }^{37}$ Additionally, preventive guidelines and caregiver education showed improvement in oral health care among dependent elders who received assistance from a preventive and curative oral health-care program. ${ }^{29}$ Besides team training, it is essential to establish periodic consultations of LTCI elders with the dentist for prevention, diagnosis, and treatment of oral diseases.

It is important to note that OGOLI's recommendations are appropriate for the LTCI context. However, some recommendations, such as chlorhexidine prescriptions and fluoride mouthwashes, must be revised over time as scientific evidence is continuously updated. As work at LTCIs is collaborative between oral health professionals and care providers, adaptations to the guideline can be made considering the resources available and organizational features of each institution. Although the original authors of the guideline reported the quality assessment of OGOLI using the AGREE, the results of this assessment were not available. As future research, efforts must be made so that the guideline is replicated in the Brazilian context, and the appropriateness, acceptability, feasibility, and applicability are evaluated through implementation research. Thus, a quality oral health care is expected 
through multi-professional work including dentists, elderly caregivers, and nursing staff. ${ }^{38}$

\section{Conclusion}

The mapping review showed that there are few evidence-based guidelines for the oral care of institutionalized dependent elders reporting oral hygiene recommendations. OGOLI was the identified evidence-based guideline for oral health care of institutionalized elders, and the cross-cultural equivalence was verified between OGOLI and its Brazilian Portuguese version.

\section{Acknowledgments}

Raquel Conceição Ferreira received financial support from FAPEMIG, Brazil (Fundação de Amparo à Pesquisa do Estado de Minas Gerais Programa Pesquisador Mineiro - PPM-00603-18). This study was financed in part by the Coordenação de Aperfeiçoamento de Pessoal de Nível Superior Brasil (CAPES) - Finance Code 001.

\section{References}

1. Instituto Brasileiro de Geografia e Estatística - IBGE. Sinopse dos resultados do Censo 2010. Brasília, DF: Instituto Brasileiro de Geografia e Estatística; 2012 [cited 2019 dez 10]. Available from: https://censo2010.ibge.gov.br/sinopse/webservice/

2. Ministério da Saúde (BR). Estatuto do ildoso. 3rd ed. Brasília, DF: Ministério da Saúde; 2013.

3. Marengoni A, Angleman S, Melis R, Mangialasche F, Karp A, Garmen A, et al. Aging with multimorbidity: a systematic review of the literature. Ageing Res Rev. 2011 Sep;10(4):430-9. https://doi.org/10.1016/i.arr.2011.03.003

4. Ferreira RC, Gonçalves TX, Soares AR, Carvalho LR, Campos FL, Ribeiro MT, et al. Dependence on others for oral hygiene and its association with hand deformities and functional impairment in elders with a history of leprosy. Gerodontology. 2018 May;35(3):237-45. https://doi.org/10.1111/ger.12346

5. Garrido Urrutia C, Romo Ormazábal F, Espinoza Santander I, Medics Salvo D. Oral health practices and beliefs among caregivers of the dependent elderly. Gerodontology. 2012 Jun;29(2):e742-7. https://doi.org/10.1111/j.1741-2358.2011.00553.x

6. Fávaro-Moreira NC, Krausch-Hofmann S, Matthys C, Vereecken C, Vanhauwaert E, Declercq A, et al. Risk factors for malnutrition in older adults: a systematic review of the literature based on longitudinal data. Adv Nutr. 2016 May; $7(3): 507-22$. https://doi.org/10.3945/an.115.011254

7. Liu C, Cao Y, Lin J, Ng L, Needleman I, Walsh T, et al. Oral care measures for preventing nursing home-acquired pneumonia. Cochrane Database Syst Rev. 2018 Sep;9:CD012416. https://doi.org/10.1002/14651858.CD012416.pub2

8. Negrini TC, Koo H, Arthur RA. Candida-bacterial biofilms and host-microbe interactions in oral diseases. Adv Exp Med Biol. 2019;1197:119-41. https://doi.org/10.1007/978-3-030-28524-1_10

9. Chalmers JM, Pearson A. A systematic review of oral health assessment by nurses and carers for residents with dementia in residential care facilities. Spec Care Dentist. 2005 Sep-Oct;25(5):227-33. https://doi.org/10.1111/j.1754-4505.2005.tb01654.x

10. Naito M, Kato T, Fujii W, Ozeki M, Yokoyama M, Hamajima N, et al. Effects of dental treatment on the quality of life and activities of daily living in institutionalized elderly in Japan. Arch Gerontol Geriatr. 2010 Jan-Feb;50(1):65-8. https://doi.org/10.1016/i.archger.2009.01.013

11. Wang TF, Huang CM, Chou C, Yu S. Effect of oral health education programs for caregivers on oral hygiene of the elderly: A systemic review and meta-analysis. Int J Nurs Stud. 2015 Jun;52(6):1090-6. https://doi.org/10.1016/i.ijnurstu.2015.01.015

12. Albrecht M, Kupfer R, Reissmann DR, Mühlhauser I, Köpke S. Oral health educational interventions for nursing home staff and residents. Cochrane Database Syst Rev. 2016 Sep;9:CD010535. https://doi.org/10.1002/14651858.CD010535.pub2

13. Ferreira RC, Schwambach CW, Magalhães CS, Moreira AN. [Dental care and oral hygiene practices in long-term geriatric care institutions]. Cienc Saude Colet. 2011 Apr;16(4):2323-33. Portuguese. https://doi.org/10.1590/s1413-81232011000400032

14. Medeiros PA, Fortunato AR, Viscardi AA, Sperandio FF, Mazo GZ. [Instruments developed for the management and care of the elderly in long-stay care institutions: a systematic review]. Cien Saude Colet. 2016 Nov;21(11):3597-610. https://doi.org/10.1590/1413-812320152111.09912015

15. InformedHealth.org. What are clinical practice guidelies? Cologne: Institute for Quality and Efficiency in Health Care; 2006 [cited 2016 Jun 15]. Available from: https://www.ncbi.nlm.nih.gov/books/NBK390308/

16. Burgers JS, Grol R, Klazinga NS, Mäkelä M, Zaat J. Towards evidence-based clinical practice: an international survey of 18 clinical guideline programs. Int J Qual Health Care. 2003 Feb;15(1):31-45. https://doi.org/10.1093/intghc/15.1.31 
17. Gil-Montoya JA, Mello AL, Cardenas CB, Lopez IG. Oral health protocol for the dependent institutionalized elderly. Geriatr Nurs. 2006 Mar-Apr;27(2):95-101. https://doi.org/10.1016/i.gerinurse.2005.12.003

18. Moher D, Liberati A, Tetzlaff J, Altman DG. Preferred reporting items for systematic reviews and meta-analyses: the PRISMA statement. PLoS Med. 2009 Jul;6(7):e1000097. https://doi.org/10.1371/journal.pmed.1000097

19. De Visschere LM, Putten GJ, Vanobbergen JN, Schols JM, Baat C. An oral health care guideline for institutionalised older people. Gerodontology. 2011 Dec;28(4):307-10. https://doi.org/10.1111/j.1741-2358.2010.00406.x

20. Khan GS, Stein AT. [Cross-cultural adaptation of the instrument Appraisal of Guidelines for Research \& Evaluation II (AGREE II) for assessment of clinical guidelines]. Cad Saude Publica. 2014 May;30(5):1111-4.Portuguese. https://doi.org/10.1590/0102-311X00174912

21. Herdman M, Fox-Rushby J, Badia X. A model of equivalence in the cultural adaptation of HRQoL instruments: the universalist approach. Qual Life Res. 1998 May;7(4):323-35. https://doi.org/10.1023/A:1008846618880

22. Beaton DE, Bombardier C, Guillemin F, Ferraz MB. Guidelines for the process of cross-cultural adaptation of self-report measures. Spine. 2000 Dec;25(24):3186-91. https://doi.org/10.1097/00007632-200012150-00014

23. Sarin J, Balasubramaniam R, Corcoran AM, Laudenbach JM, Stoopler ET. Reducing the risk of aspiration pneumonia among elderly patients in long-term care facilities through oral health interventions. J Am Med Dir Assoc. 2008 Feb;9(2):128-35. https://doi.org/10.1016/i.jamda.2007.10.003

24. Putten GJ, De Visschere L, Vanobbergen J, Schols JM, Baat C. [The guideline Oral Health Care for dependent residents in long term care facilities, 2007: dire necessity!]. Tiidschr Gerontol Geriatr. 2008 Oct;39(5):202-7. Dutch. https://doi.org/10.1007/bf03078154

25. Borsa JC, Damasio BF, Bandeira DR. [Cross-cultural adaptation and validation of psychological instruments: some considerations]. Paidéia. 2012 Dec;22(53):423-32. Portuguese. https://doi.org/10.1590/S0103-863X2012000300014

26. De Visschere L, Schols J, Putten GJ, Baat C, Vanobbergen J. Effect evaluation of a supervised versus non-supervised implementation of an oral health care guideline in nursing homes: a cluster randomised controlled clinical trial. Gerodontology. 2012 Jun;29(2):e96-106. https://doi.org/10.1111/j.1741-2358.2010.00418.x

27. Putten GJ, Mulder J, Baat C, De Visschere LM, Vanobbergen JN, Schols JM. Effectiveness of supervised implementation of an oral health care guideline in care homes; a single-blinded cluster randomized controlled trial. Clin Oral Investig. 2013 May;17(4):1143-53. https://doi.org/10.1007/s00784-012-0793-2

28. De Visschere L, Baat C, Schols JM, Deschepper E, Vanobbergen J. Evaluation of the implementation of an 'oral hygiene protocol' in nursing homes: a 5 -year longitudinal study. Community Dent Oral Epidemiol. 2011 Oct;39(5):416-25. https://doi.org/10.1111/j.1600-0528.2011.00610.x

29. Janssens B, Vanobbergen J, Petrovic M, Jacquet W, Schols JM, De Visschere L. The impact of a preventive and curative oral healthcare program on the prevalence and incidence of oral health problems in nursing home residents. PLoS One. 2018 Jun;13(6):e0198910. https://doi.org/10.1371/journal.pone.0198910

30. Connis RT, Nickinovich DG, Caplan RA, Arens JF. The development of evidence-based clinical practice guidelines. Integrating medical science and practice. Int J Technol Assess Health Care. 2000;16(4):1003-12. https://doi.org/10.1017/S0266462300103071

31. Conselho Federal de Enfermagem - Cofem. Resolução N 0509, de 4 de abril de 2016 [cited 2020 Mar 18]. [Defines the duties of the nurse responsible technician]. Portuguese. Available from: http://www.cofen.gov.br/resolucao-cofen-no-05092016-2_39205.html

32. Ministério da Saúde (BR). Portaria N 1.996, de 20 de agosto de 2007 [cited 2020 Mar 18]. [Provides for the guidelines for the implementation of the Política Nacional de Educação Permanente em Saúde]. Portuguese. Available from: http://bvsms.saude.gov. br/bvs/saudelegis/gm/2007/prt1996_20_08_2007.html\#: :text=PORTARIA\%20N\%C2\%BA\%201.996\%2C\%20DE\%2020,de\%20 Educa\%C3\%A7\%C3\%A3○\%20Permanente\%20em\%20Sa\%C3\%BAde

33. Conselho Federal de Odontologia - CFO. Resolução No 42, de 20 de maio de 2003 [cited 2020 mar 18]. [Defines the Code of Ethics in Dentistry]. Portuguese. Available from: http://www.lex.com.br/doc_25974_RESOLUCAO_N_42_DE_20_DE_MAIO_DE_2003.aspx

34. James $P$, Worthington HV, Parnell C, Harding M, Lamont T, Cheung A, et al. Chlorhexidine mouthrinse as an adjunctive treatment for gingival health [Review]. Cochrane Database Syst Rev. 2017 Mar;3:CD008676. https://doi.org/10.1002/14651858.CD008676.pub2

35. Ochi N, Yamane H, Honda Y, Takigawa N. Accidental aspiration of denture cleanser tablets caused severe mucosal edema in upper airway. Clin Respir J. 2018 Jan;12(1):291-4. https://doi.org/10.1111/cri.12468

36. Janssens B, De Visschere L, Putten GJ, Lugt-Lustig K, Schols JM, Vanobbergen J. Effect of an oral healthcare protocol in nursing homes on care staffs' knowledge and attitude towards oral health care: a cluster-randomised controlled trial. Gerodontology. 2016 Jun;33(2):275-86. https://doi.org/10.1111/ger.12164

37. Weintraub JA, Zimmerman S, Ward K, Wretman CJ, Sloane PD, Stearns SC, et al. Improving nursing home residents' oral hygiene: results of a cluster randomized intervention trial. J Am Med Dir Assoc. 2018 Dec;19(12):1086-91. https://doi.org/10.1016/i.jamda.2018.09.036

38. Raghavendran K, Mylotte JM, Scannapieco FA. Nursing home-associated pneumonia, hospital-acquired pneumonia and ventilator-associated pneumonia: the contribution of dental biofilms and periodontal inflammation. Periodontol 2000. 2007;44(1):164-77. https://doi.org/10.1111/j.1600-0757.2006.00206.x 